\title{
COMPREHENSIVE INTEGRATION AS AN EFFECTIVE WAY OF TRAINING FUTURE DESIGNERS AT TECHNICAL UNIVERSITIES (INTEGRATION AS A WAY OF TRAINING A DESIGNER)
}

\author{
Nadezhda Zhdanova*, Sergey Gavrytskov, Anna Ekaterynushkina, Julia Mishukovskaya, Julia Antonenko \\ Nosov Magnitogorsk State Technical University, Russia
}

The article deals with the possibilities of comprehensive integration as a way to upgrade the professional training of designers. The authors see a means of resolving some problems of design education in it. To realize this goal, a prognostic model was developed, linking all the components: the content, methodology of the teacher's work, and student activities. This model was built on the basis of data obtained in the process of studying the activities of design practitioners, for which a survey was carried out and an interview was held with each of them. Particular attention was paid to the difficulties experienced by young designers in the first years of their work, as well as experienced professionals, watching their young colleagues' activities. The authors propose to use both "vertical" and "horizontal" integration in the learning process, since each has its own advantages. In this case, the formation of future designers' necessary competences is completely ensured, which should be manifested in a holistic and flexible thinking capable of solving design problems of any complexity level. To check the availability of such thinking, a special task was developed in the field of environmental design. Students designed the product from construction waste, thereby solving the actual problem of recycling and reuse of old materials. The purpose of this article is the authors' desire to share their accumulated work experience, to give the pedagogical community the opportunity to discuss the results obtained for the further implementation of the integrative approach in the professional training of future designers.

Key words: Comprehensive integration, Professional training of the designer, Intersubject links, Designer's personal qualities, Integration model, Activity, Designing

\section{INTRODUCTION}

Constant demand for designers has determined the intensive training of these specialists in various educational institutions, and the changing conditions for their work have caused adjustments of the competences formed. It has led to a need for a structural analysis of the very professional activities of designers, learning the productive experience of other educational institutions, creating educational and methodological materials, and, most importantly, determining the directions for specifying the model of the future professional. Pedagogical integration has become one of the effective ways to solve all these problems. It is an important requirement of modern science and the development of civilization as a whole. To create a holistic picture of the world for future designers is possible only on the basis of an integrative approach to the whole educational process. However, pedagogical integration as a rather recent phenomenon has not yet been thoroughly studied and is being implemented not in all educational areas.

After studying the bibliographic sources and experience of some educational institutions, as well as the educational practice at our institute, the conviction appeared that in case an integrative approach to all parts of the educational process is implemented, the overall effect will be much higher than that from certain actions of these components.
The purpose of our experimental work was to introduce a prognostic educational model integrating separate parts of the learning process to form a complex thinking in the future designer, which would ensure the ability to carry out projects of different orientations at a sufficiently high level.

The implementation of this model was carried out for more than 10 years; at the end of each academic year, the teaching methodology, teaching tools and integrated parts were adjusted, and the members of the staff were partially substituted. At the same time, from year to year it narrowed, steady positions were identified, which ensured the effectiveness of the integrated process.

The experience of implementing an integrative approach in the educational process offered by a team of authors can be useful for all stakeholders.

\section{LITERATURE REVIEW}

It cannot be said that the path chosen by us was entirely new. In the history of design education, there are positive examples of using integration and getting highly successful results.

This is primarily the work of the Bauhaus and the UIm School of Design in Germany. The high school of building and artistic design - BAUHAUS, which existed from 1919 to 1933 in Germany, showed the first and most successful form of integration - theory and practice [01, 02]. 
The developed methodology of training future designers formed the basis for the organization of all higher educational institutions [03, 04]. Revived after the Second World War, design education at the UIm School of Design made every effort to integrate science, technology and art, which was embodied in continuing and very successful experiments with form and materials [05, 06].

Good results were also obtained by British teachers who combined the project activities with the practical implementation of the developed subject [07]. In fact, it was also the integration of different types of activities only at the level of secondary vocational education.

In Russia, the idea of integrated design education came in the mid-90s of the 20th century and was characteristic of all levels of education [08, 09, 10]. One of the first to respond was the teachers who introduced the design into the general education schools [11], then the higher school [12, 13] was involved. Unfortunately, for a long time the experience gained in some educational institutions was not generalized, and most importantly it was not transferred from one stage of education to another [03]. In the mid-90s of the $20^{\text {th }}$ century, the first state standards appeared in Russia, in which the most common approaches to the professional model of any specialist were put forward. It was them that constituted the basis for students' education in higher educational institutions. The fundamental difference was the transition to a competence model, which includes theoretical knowledge, practical skills, as well as certain personal qualities purposefully educated [14, 15]. Acquisition of the necessary competences can be achieved in different ways. One of them is comprehensive integration, that is, the unification in the educational process of various forms and kinds of activities, or the combination of previously separately existing parts of training into a single whole [13].

The integration, substantiated in pedagogy, made it possible to change attitudes towards it. First, the integration objectives were theoretically formulated and it became clear that they could be different. Then its main elements were defined. They are:

- designed purpose (direction of integration);

- the composition of the integration process (integration objects);

- the form of pedagogical integration;

- types of pedagogical integration;

- system-forming factor of integration [16].

During the next twenty years the possibilities of integration for different levels and directions of education, including design, were tested [17]. Theorists proposed to consider two types of integration: vertical and horizontal. For the design education, vertical integration seemed at first much more important. It provided for continuity between different levels of education, as well as interaction with various public institutions and enterprises; it became possible to link teaching design of schoolchildren and students with a single goal and a unified methodology.
The old principle of succession and continuity has acquired a new dimension. If in the Soviet era, only some art schools could afford preparatory schools at faculties and institutes [18], then in the early 90 s of the $20^{\text {th }}$ century a rather large number of supplementary education institutions opened in the whole country, teaching one or another kind of design [11, 19], which indicated an increased interest in the profession and the importance of design skills. They were regarded as the main means of developing creative abilities; this point of view still dominates today [20].

The city of Magnitogorsk did not stay on the sidelines. In the late 80-ies here a comprehensive school № 63 was launched, where the design was taught to all children from the first to the eleventh grade. Here the goal of integration was the unification of general and special education, checking how much the design activity contributes to students' learning. The results of the activity were repeatedly discussed at scientific and practical conferences of different levels, and work experience was touched upon in a number of publications, including study guides for students and teachers [21].

However, it should be noted that vertical integration covered only a small percentage of schoolchildren, in fact only those whose learning was focused on the future professional work in the arts, because by the beginning of the century the interest in it began to fade, publications diminished progressively and they mainly described practical experience of certain educational institutions without theoretical generalizations.

When it comes to horizontal integration, the term interdisciplinary is often used, although, ultimately, integrated elements can be modules, whole units of courses, units of programs, projects, etc. The purpose and the system-forming factors are much more important in integration. In the process of implementing integration, the following rules should be adhered to:

- definition of integrated objects;

- highlighting factors that contribute to integration and interfere with it;

- forecasting potential outcomes taking into account the needs and characteristics of participants in the educational process.

For higher education institutions, it is important to highlight those factors that contribute to or impede integration, and thus to achieve the final outcome. The most important factor is the demand for designers in the labor market. This factor can play both a positive and a negative role. Educational institutions constantly monitor it through interaction with the labor exchange and graduates. On the basis of the data, they specify on their own which specialist is needed today and will be in demand tomorrow that respond to requests of the country, region, certain city, or enterprise. This explains the significant differences in the professional training of graduates at different educational institutions [22]. 
The study of works by foreign authors has revealed that interdisciplinary education is an urgent issue at present. Knowledge integration is involved in the learning processes in higher education [23, 24, 25]. The scholars argue that currently, "gaining an insight into the nature of interdisciplinary education may help when making design decisions for interdisciplinary education" [26]. They pay attention to certain parameters while analyzing interdisciplinary education. For instance, they speak about complicated, actual problems which are addressed to "in pedagogical formats such as problem-based learning formats, case studies, field-work, discovery or inquiry learning" [26]. Among other aspects related to interdiciplinarity in higher education which are touched upon in scientific articles are: interdisciplinarity in the engineering classroom [27], designing interdisciplinary postgraduate curricula (at the Research-intensive UK University) [28], interdisciplinary teaching and learning for diverse and sustainable engineering education [29], the important role of teachers in this process ('the caring teacher' in the context of the higher education environment) [30], etc.

Over the past years, many universities have incorporated sustainability into their education and research. The articles describe "the integration of competences for sustainable development in higher education" [31]; the way in which a multidisciplinary approach to teaching and learning sustainability has been included in learning programs and activities in engineering at the University of Surrey, UK [32]. In many papers the notions of sustainability and eco-design are interconnected and interrelated [33, 34, 35].

Integration of theory and practice in higher education is another aspect deserving attention [29, 36, 37]. A substantial provision for the integration of theory and practice in higher education is the synergy between the higher education establishment and industry. The annual research accomplished by the Confederation of Swedish Enterprise demonstrates that eight out of ten students prefer higher education to advance their qualifications on the employment market [38]. The so-called "work integrated learning (WIL)" is a strategic thrust for universities focusing to upgrade graduate employability in a labour market [39]. The "integrated design approach" is supported by students' training in cross-disciplinary teams. An example of this approach is the EU-project of IDESEDU "Master and Post-Graduate education and training in multi-disciplinary teams" [40].

Another aspect which was driven attention to is the research-based curricula. The turn to research-based education took place under the influence of the Bologna process and strong impact of such organizations as OECD, European Ministers of Education, Commission of the European Communities [41]. It presumes that students must actively participate and be socialized into the pursuance of the research. Research-based curricula aids at developing " $21^{\text {st }}$ century skills, such as active learning, critical reflection and problem-solving. Students should take a position as knowledge creators rather than knowledge recipients" [41]. The United Nations Decade of Education for Sustainable Development conducted by the UNESCO $(2005-2014)$ is worth mentioning too in enhancing the research-based education [42].

Taking into consideration the significance of environmental issues and the necessity and desire to cope with them relating to different fields, eco-design has become of paramount importance. This is a concept comprising "human sustainability priorities together with business interrelations. Its main objective in the improvement of product development methods is to reduce environmental loads" [43]. EcoDesign also comprises an aim "to use inspiration from a wider field of positive examples of smart products and methods, effective system solutions and attractive designs" [43].

While analyzing issues related to eco-design, the authors describe the development and use of various environmental improvements: the use of an alternative energy system [33], the environmental value of longer lasting products which induces the introduction of the ecological payback period [34], elaboration of life cycle design: from regular techniques to product type specific guidelines and checklists (for instance, in a case of developing guidelines for the eco-efficient design of NECTA vending machines) [35]; the management of mass products at the end-of-life [44], application of eco-design tools (eco-roadmapping, lifecycle assessments, etc.) [45] and many others [46, 47, 48, 49].

Various tools are applied when teaching and learning eco-design. Among them are design protocol analysis, which is a technique to comprehend designers' cognitive procedures by studying series of observed results concerning their behavior. They apply audio, video, transcript data, sketches, sensor data and user logs with the usage of VizScribe, a visual analytics framework which helps analyze both the designer's behavior and the design process [50]. An evidence-based approach grounded on virtualization and virtualization technology is a powerful teaching and learning tool in the system of higher education [51, 52].

The creation of web-based resources (for instance, www. design-behaviour.co.uk at the Department of Design and Technology at Loughborough University), is a supportive measure in centralizing and disseminating teaching material on the subject of Design for Behavioural Change [53]. Nowadays immersive Virtual Reality (VR) technologies are frequently applied as advanced training systems for future designers. These specialists are demanded to investigate different fields of engineering in order to master the relevant knowledge about the product, the problems of its operation, its impact on the natural environment, etc. Dealing the products that are taken away from usage is one of the urgent issues. One of the ways to fix these problems is taking into consideration these issues in the opening phase of the product design. Authors created the methodology to comprise recycling demands in the phase of the product design that was made with sup- 
port of the CAD 3D systems. The study of recycling of the chosen product designed in the CAD 3D system was carried out using Virtual Reality technologies [54]. Thus, future designers had possibility to upgrade their skills and knowledge in the sphere of eco-design "through the immersive trainings of virtual product design for recycling" [54].

Some scientific articles describe students' various eco-design activities: greening of a campus community through 3R (reduce, reuse and recycle) waste management initiatives [55]; the first experiences of an undergraduate student team with eco-design activities [56], etc.

The conclusions of the above-mentioned publications admit the significance of advancing holistic tools for designers, recognizing that the synthesis of guidance, education and information, in addition to well-considered content, proper application and convenient access, are all important to their achievements [57].

\section{MATERIALS AND METHODS}

Like every scientific research, our experimental work began with a theoretical analysis of information resources and with the search of the available practical educational experience.

The main method in our work was the modeling and the introduction into the educational process of the prognostic model of integration. At the beginning, an attempt was made to introduce existing educational models developed by other educational institutions.

In the late 80 s of the $20^{\text {th }}$ century, the teachers at Stroganov Moscow State University of Arts and Industry developed the first variant of the qualification characteristics of future designers - a document that is a concentrated verbal model of a specialist. Then such a model was understood as an image established documentarily, what kind of specialist he/she should be for a certain period of time, and besides, the means of its training were determined. "The model includes a certification of a specialist and the training format" [18]. In the certification the requirements of the society were recorded in relation to the sphere of labor activity; job duties, business qualities and intellectual properties. It was assumed that the system of training in a university should correspond to the socio-professional requirements recorded in the passport. When creating the first generation of state educational standards, this point of view was adhered to, therefore units were created based on the informative value of certain disciplines.

Over the past 15 years, state educational standards in Russia have been changed three times, which led to a change in the perception of the specialist's model three times; today, as mentioned above, everyone has switched to a competency-based approach in the training of future designers.

Our experimental work was carried out in several stages:
- the first stage: the simulation of the educational process was carried out on the basis of the three units of competencies available in the state educational standard for the bachelor's degree in major "Design".

- the second stage: the identification of competencies which were missing, but demanded in the professional activity of designers;

- the third stage: the simulation of the educational process was carried out with the inclusion of a new fourth unit of additional competencies.

After each stage, the model was tested and the obtained outcomes were discussed by the entire teaching staff.

The first stage began with the study of competencies and the creation of educational methodological material for its implementation. In all standards, there are three main units that combine competence in the direction of:

\section{- a unit of general cultural competence; \\ - a unit of general professional competence; \\ - a unit of professional competencies.}

The unit of general cultural competencies is aimed at the development of generalized abilities that provide students' general education, therefore, they are repeated in fields of education. This includes abilities to use the foundations of philosophical, historical, economic and legal knowledge in various fields of activity, the readiness of social and ethical responsibility for decisions to be made, knowledge of methods of self-organization and self-education.

The unit of general professional competencies is aimed at the formation of universal artistic abilities in the field of drawing, painting, sculpture, aesthetics and artistic creativity. Here, special attention is paid to the knowledge of folk traditions, modern trends in arts and issues of artistic synthesis, issues of color science, means of artistic composition, patterns and techniques for the reproduction of artistic design in certain materials. Particularly distinguished are the abilities to search, store, process and analyze information from various sources and databases that determines the student's information and bibliographic culture.

The unit of professional competences contains the competences related to the types of activities chosen by every institution, but the analysis of more than three dozen curricula of different educational institutions that train designers demonstrates that almost every curriculum comprises the first three types: artistic, design and information technology. Everyone recognizes that artistic abilities have a decisive role in designing that figurative concepts contribute to the design of objects, goods, industrial designs, complexes and objects at a competitive level.

Visually, at first, our model was presented in the form of a triangle, in the center of which there was a student with the required competences. The above-mentioned units with main activities were based on each side. To confirm such a model, we decided to compare its competencies 
with those that practicing designers use in their work and compare the model with the benchmark.

The second stage was devoted to the study of professional designers' activities. Two sociological methods were used here: interview and questionnaires, as well as analysis of implemented projects. It was self-analysis and evaluation of their designers' own activities.

The most effective form of collecting information is an interview with each designer and analysis of the success of his/her professional activity. Some of the required information was collected by the questionnaire method, which allowed a quick survey of personal data. At first, the respondent filled out his age, which educational establishment and when he graduated from, the number of years of professional experience, places of employment and the reasons for change of employment. The next section of questions dealt with the current state of affairs: the status of the enterprise (state or commercial), the specialization of the enterprise (environmental, architectural or graphic design, construction or advertising company, design bureau, private entrepreneur, etc.), job title and area of responsibility. In the next column, the respondent mentioned the major implemented projects, noting whether they retained the author's concept and why they were modified. And, finally, the difficulties that he/she faced as a professional designer. Designers of different ages and length of work in the Urals region were surveyed. For more details, see N.S. Zhdanova's publication [09].

Most of the respondents were interviewed according to the pre-elaborated and pre-developed questions with the timely recording of the obtained data. There were also improvisations that helped to clarify the nature of the difficulties of designers' professional activity, especially in the first years of work. Along with the difficulties that are not relevant to this article, we have identified a fairly large range of problems of purely designer's activity. The questionnaire survey showed that in our region only $52 \%$ of practicing designers have a design, architectural and artistic education, so the range of missing competencies was also quite large.

Particular attention was paid to design graduates at different universities. In the first five years of work, they complain about the lack of economic knowledge, allowing to launch small enterprises and correctly assess the economic costs for implementing a particular project; the lack of design and construction data, allowing to carry out re-planning of certain buildings and structures, and knowledge of specific art crafts and modern technologies.

As a result of the survey, there was another gap in the professional training of designers: a lack of willingness to participate and organize exhibition activities. In the field of design, exhibitions of design work and various proposals are often held. Sometimes they are accompanied by forums related to certain promising areas of design work. It turned out that not every designer is ready to discuss and evaluate new project proposals. Even more often, designers participate in the organization of exhibition displays for certain goods or services and sometimes personally participate in them. The ability to personally advertise products is by no means last skill in the designer's work.

The interview with professional designers with a lengthy employment history included a number of issues related to the activities of their young colleagues. Despite some ethical difficulties in these surveys, it was possible to collect some useful information and add those missing abilities, the absence of which prevents from working properly by graduates in the first years after graduating from universities. This, above all, includes the ability to communicate with customers and an objective assessment of graduates' own activities.

The third stage of experimental work began with the formation of the fourth unit of special, or in new terminology, additional competences. The unit system initially provided for integration, so immediately new components were integrated with the old ones.

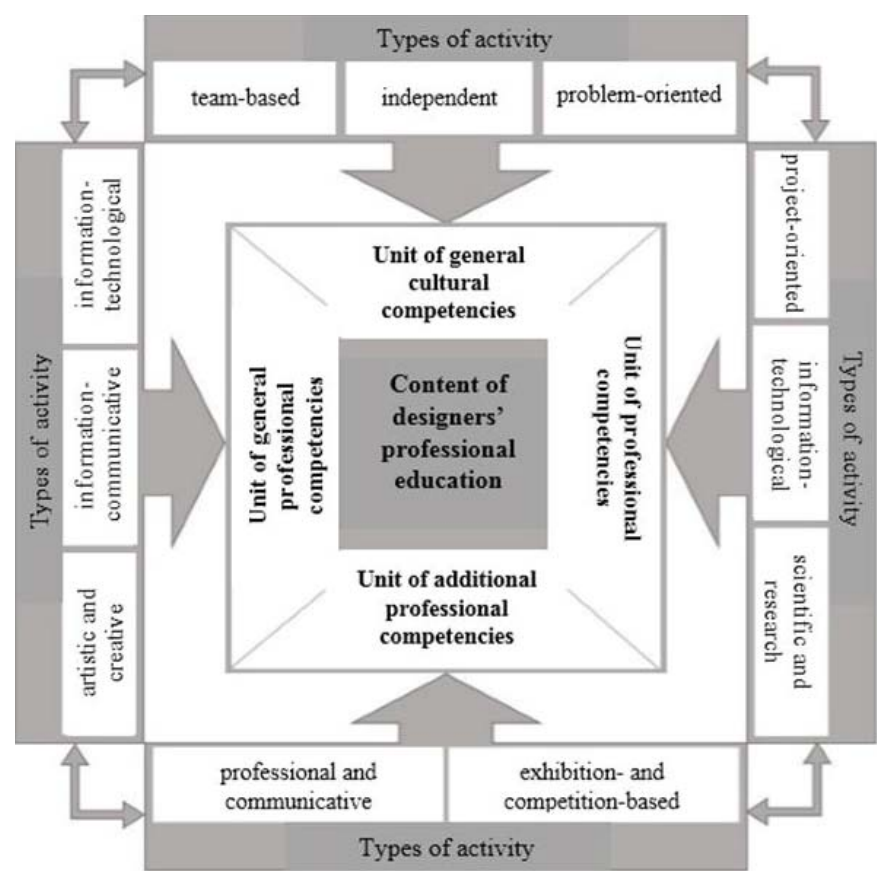

Figure 1: The model of interaction of different units in designers' professional training

A model was created where all four units of the curriculum are interrelated (Figure 1). However, the mere introduction of additional disciplines is not enough; it is not sufficient for specialist's professional training in case they are not included in the general system of education and upbringing. Right away, the content and methodology of some academic disciplines were adjusted, more time was devoted to professional and communicative activities, interpersonal communication, the ability to substantiate and defend their project proposals at each stage of their implementation. 
The center of the model is the content of professional training, and the external background consists of four units of disciplines to study. Large arrows indicate the direct impact of certain activities on students' competencies. Due to the integration, there are more close links between the units themselves and their components, as shown by semicircular arrows. By all means, no scheme reflects the entire completeness of the simulated phenomenon; it only makes it possible to show the most significant connections.

Based on the theoretical characteristics of integration, taking into account its elements, it is possible to create various integration objects. By changing the combinations of integration elements, it is possible to obtain fundamentally new types of integration. In our case, first of all, it contributed to the correct combination of team-based, independent and problem-oriented activity in the unit of general cultural competencies: artistic and creative, information-communicative and information-technological activities in the unit of general professional competencies; students' project-oriented, information-technological and scientific and research activities in the unit of professional competencies. The fourth unit was discussed above, but here we want to note that the units themselves interact with each other.

In the process of implementing an integrative model, much depends on the teaching staff, which sets an example and teaches the professional language of design. Intersubject integration requires of teachers to develop a single "pedagogical" strategy, the obligatory reciprocity of use of certain concepts and facts by them not only in the development of training courses, but also in communicating with students. These requirements should be considered not only essential, but also sufficient indicators for integrated teaching. The main thing that makes the course integrated is the long-term goal set in it and specific tasks aimed at its implementation, planned by all the teachers who carry out professional training. This goal is realized by them in students' activities specially organized.

The basis for integration was the joint efforts of teachers to create students' certain professional skills and proficiencies, overcoming isolated teaching of subjects, the generality of the selected topics, the similarity of the objects and phenomena studied, and the unity of the key ideas envisaged in the programs. In any case, the task of teachers who form the integrated unit of subjects is to find ways of processing the elements of content and structure of their academic disciplines to form students' integral creative thinking.

\section{RESULTS}

To check the achieved results, the students were asked to perform a complex task. They had to design furniture objects from recycled materials. As a rule, they were household or construction waste. The task led students to a new level of thinking - an ecological one. The idea of recycled materials usage today unites a multitude of fashion trends in art and design, as well as hand-made techniques. Students, as a rule, are well aware of the issues of waste disposal, but have never carried out projects with their usage before.

The creative transformation of waste, as a rule, does not require additional production costs, but as a result, sometimes there are art objects, household products, accessories, clothes that surpass in their functional and aesthetic qualities the initial material. "Development of designer products from non-traditional, and, preferably, recycled materials has a lot of advantages, the most important of which is the value of the work being done" [58].

Five criteria are set for the designed products: wastefree performance, minimal technological processing of raw materials, functionality, ergonomics and aesthetic

qualities. The criterion of aesthetics includes the concept of singularity, as a manifestation of creativity. The evaluation is made on a five-point scale.

The authors of the article did not consider it necessary to present students' assessments here. In our opinion it is more important to note that they are actively initiating ecological design, but only some of them successfully complete it. It is here that integrative thinking is revealed, because the work requires an incredibly broad, flexible and creative approach, attracting all competencies and it is no longer important in which discipline, unit or program they were received.

Students' works and their description are presented in another publication of the authors [58], which also emphasizes the role of integration, which profoundly changes the content of education, leads to changes in the methods of work and creates new teaching technologies. It provides a completely new psychological climate for the teacher and student in the learning process and creates a favorable educational environment.

\section{DISCUSSION}

The process of creating a predictive model of designers' professional training was built in accordance with the model of practicing designers' activity, for which they were surveyed and interviewed according to a pre-designed plan. The obtained data indicated some missing knowledge and skills, which are especially subversive in the first years of independent work.

However, it turned out to be very difficult for many designers to analyze their own activities, because, as psychologists point out, it takes place in a "minimized form". In this regard, in our opinion, a large and objective information can be provided by videotaping the process of how the practicing designer performs a certain task. This can be included into our follow-up related to the experimental study of the design process. Beyond this article, there is some material on the educational significance of integration, without which it is impossible to train a designer. 


\section{CONCLUSIONS}

The long work of the teachers' team led everyone to the conclusion that pedagogical integration is an effective means of educating a designer with a full range of competencies and developed professional qualities of the individual. This is achieved by introducing a predictive model of integration of all parts of the learning process.

Verification of the received competencies and qualities of thinking was carried out by means of the task of the increased complexity associated with the problems of using construction waste. The project is assessed on the following levels: modernization, innovation and inovation. Comparison of the proposed ideas over the years shows the growth of all indicators. Students find new original solutions, which indicates the development of creative and holistic thinking. Subsequent product manufacturing corrects some project proposals, making them more practical.

The result of integration was the effective formation of comprehensive integrated thinking in the future designers, which manifests itself in the ability to carry out projects of different kinds. The final result of this process is the high level of designer's willingness to meet the demands of the profession in different conditions and at different levels.

\section{ACKNOWLEDGEMENTS}

Work on the introduction of an integrated model for designers' training could only take place with the support of the entire teaching staff at the department and the institute, to which we express our sincere gratitude.

We would also like to thank the Regional Office of the Designers Association of Russia, whose leadership helped implement the survey of practicing designers and organized meetings with them.

\section{REFERENCES}

1. Gropius, W. (1923). Idee und Aufbau des Staatlichen Bauhauses. Münch, Weimar.

2. Kentgens-Craig, M., Dessau, S.B. (1999). The Dessau Bauhaus Building. Birkhäuser, Basel - Berlin Boston.

3. Kondratieva, K.A. (2005). Some conceptual foundations of design education: Stroganov Moscow State Academy of Design and Applied Arts. Moscow State Stroganov University of Design and Applied Arts, Moscow.

4. Tkachenko, E.V., Kozhukhovskaya, S.M. (2007). Design education in Russia. The world of education - education in the world. Interindustry Information Service, no. 1(25), 156-164.

5. 5. Druzhkova, N.I. (2012). The Ulm Higher School of Design (1953-1968). Pedagogy of Art, no.2, from http://www.art-education.ru/sites/default/files/journal_ pdf/drugkova_12_june.pdf, accessed on 2017-09-29.
6. Bauhaus-Chronik, B.M. (1952). Vom Bauhaus in Weimar zur Hochschule für Gestaltung in Ulm. Deutsche Universitätszeitung, no. 23-24.

7. Barlex, D., Pitt, J. (1999). Technological education in schools of Great Britain. School and Production, no. 5, 93-95.

8. Antonova, N.N. (2005). From the history of development of professional design education in Russia. Scientific Information Bulletin of Doctoral Students, Post-Graduates, Students, vol. 2, no. 6, 200-205.

9. Zhdanova, N.S. (2007). Modeling the content of professional training for future designers. Bulletin of the Orenburg State University, vol. 11-2, no. 76, 52-57.

10. Tukhbatullina, L.M., Safina, L.A. (2013). Foreign experience in the application of project-based learning in polymer specialists' training. Bulletin of the Kazan Polytechnic University, no. 3, 333-335.

11. Ladygin, E.V. (2000). Development of students' creative abilities in the integrative active learning at the course "Fundamentals of Design". Moscow.

12. Banduristy, F.F. (2001). Optimization of teaching artistic design in the system of special training of the teacher of fine art in pedagogical educational establishments (universities). Prometheus, Moscow.

13. Yakovlev, I.P. (1987). Integration of the higher school with science and production. Leningrad State University Publishing House, Leningrad.

14. Tarasova, O.P., Yanysheva M.M. (2014). Formation of professional competencies of the future designer in educational and professional activity. Bulletin of the Orenburg State University, vol. 5, no. 166, 210215.

15. Fakhrutdinova, R.A., Akhmetova, G.P. (2014). Developing professional competence of students, future designers, in higher education training. Philology and Culture, vol. 2, no. 36, 298-301.

16. Bezrukova, V.S. (1994). Integration processes in pedagogical theory and practice. Russian State Vocational Pedagogical University, Ekaterinburg.

17. Aristova, U.V. (2007). Modeling of system of designers' professional training in high school. Moscow Open Social University, Moscow.

18. Moscow School of Design. The experience of training specialists in MHPU. (1991). Stroganov Moscow State University of Arts and Industry, Moscow.

19. Popugaeva, I.Ya, Ryazanov, V.N., Dolikhin, T.A. (2007). On pre-profile training on the basis of the institution of additional education of children. Education of Schoolchildren, no. 10, 40-44.

20. Babikova, V.V., Sokolov, M.V. (2017). Approaches to the development of creativity in design. Current Trends in Fine, Decorative and Applied Art and Design, no. 2, 170-175. 
21. Zhdanova, N.S. (2010). Methods of teaching design in secondary school. Magnitogorsk State University, Magnitogorsk.

22. Sirotina, I.L, Schekochikhina, O.D. (2016). Digital arts as a factor in the optimization of professional development of a designer. Proceedings of the International Scientific and Practical Conference "Russian Creative Education in the Field of Digital Art in Accordance with EU Standards", p. 233-242.

23. Flaig, M., Simonsmeier, B.A., Mayer, A.-K., Rosman, T., Gorges, J., Schneider M. (2018). Conceptual change and knowledge integration as learning processes in higher education: A latent transition analysis. Learning and Individual Differences, vol. 62, 4961, DOI: 10.1016/j.lindif.2017.12.008

24. Hotaling, L., Sheryll, R., Sheppard, K., Chassapis, C., McGrath, E. (2007). A paradigm for vertically integrated curriculum innovation - how curricula were developed for undergraduate, middle and high school students using underwater robotics. International Conference on Engineering Education - ICEE 2007, from http://ciese.org/papers/2007/icee2007_ LEGO_finalpaper.pdf, accessed on 2018-07-01.

25. Thomas, H. (2018). Powerful knowledge, technology and education in the future-focused good society. Technology in Society, vol. 52, 54-59, DOI: 10.1016/j. techsoc.2017.09.005

26. Klaassen, R.G. (2018). Interdisciplinary education: a case study. European Journal of Engineering Education, DOI: 10.1080/03043797.2018.1442417

27. Richter, D.M., Paretti, M.C. (2009). Identifying barriers to and outcomes of interdisciplinarity in the engineering classroom. European Journal of Engineering Education, vol. 34, no. 1, 29-45, DOI: 10.1080/03043790802710185

28. Gantogtokh, O., Quinlan, K.M. (2017). Challenges of designing interdisciplinary postgraduate curricula: Case studies of interdisciplinary master's programmes at a research-intensive UK university. Teaching in Higher Education, vol. 22, no. 5, 569586, DOI: 10.1080/13562517.2016.1273211

29. Wachter, C. (2012). Interdisciplinary teaching and learning for diverse and sustainable engineering education. Béraud, A., Godfroy, A.S., Michel, J. (Eds.), GIEE 2011: Gender and Interdisciplinary Education for Engineers. Sense Publishers, Rotterdam, p. 4763, DOI: 10.1007/978-94-6091-982-4_5

30. Walker, C. , Gleaves, A . (2016). Constructing the caring higher education teacher: A theoretical framework. Teaching and Teacher Education, no. 54, 6576, DOI: 10.1016/j.tate.2015.11.013
31. Lambrechts, W., Mulà, I., Ceulemans, K., Molderez, I., Gaeremynck, V. (2013). The integration of competences for sustainable development in higher education: an analysis of bachelor programs in management. Journal of Cleaner Production, vol. 48, 65-73, DOI: 10.1016/j.jclepro.2011.12.034

32. Perdan, S., Azapagic, A., Clift, R. (2000). Teaching sustainable development to engineering students. International Journal of Sustainability in Higher Education, vol. 1, no. 3, 267-279, DOI: 10.1108/14676370010378176

33. Jansen, A., Stevels, A. (2006). Combining eco-design and user benefits from human-powered energy systems, a win-win situation. Journal of Cleaner Production, vol. 14, no. 15, 1299-1306, DOI: 10.1016/j. jclepro.2005.11.023

34. van Nes, N., Cramer, J. (2006). Product lifetime optimization: a challenging strategy towards more sustainable consumption patterns. Journal of Cleaner Production, vol. 14, no. 15-16, 1307-1318, DOI: 10.1016/j.jclepro.2005.04.006

35. Vezzoli, C., Sciama, D. (2006). Life cycle design: from general methods to product type specific guidelines and checklists: a method adopted to develop a set of guidelines/checklist handbook for the eco-efficient design of NECTA vending machines. Journal of Cleaner Production, vol. 14, no. 15, 1319-1325, DOI: 10.1016/j.jclepro.2005.11.011

36. Filho, W.L., Shiel, C., Arminda P. (2016). Implementing and operationalising integrative approaches to sustainability in higher education: the role of project-oriented learning. Journal of Cleaner Production, vol. 133, 126-135, DOI: 10.1016/j.jclepro.2016.05.079

37. Figueiró, P.S., Raufflet, E. (2015). Sustainability in higher education: a systematic review with focus on management education. Journal of Cleaner Production, vol. 106, 22-33, DOI: 10.1016/j.jclepro.2015.04.118

38. 38. Arnesson, K., Albinsson, G. (2012). Integration of theory and practice in higher education. International Journal of Educational Research, vol. 53, 370-380, DOI:10.1016/j.ijer.2012.05.002

39. Schuster, L., Glavas, Ch. (2017). Exploring the dimensions of electronic work integrated learning (eWIL). Educational Research Review, vol. 21, 5566, DOI: 10.1016/j.edurev.2017.04.001

40. Brunsgaard, C., Dvořáková, P., Wyckmans, A., Stutterecker, W., Laskari, M., Almeida, M., Kabele, K., Magyar, Z., Bartkiewicz, P., Op't Veld, P. (2014). Integrated energy design - Education and training in cross-disciplinary teams implementing energy performance of buildings directive (EPBD). Building and Environment, vol. 72, 1-14, DOI: 10.1016/j.buildenv.2013.10.011 
41. Afdal, H.W., Spernes, K. (2018). Designing and redesigning research-based teacher education. Teaching and Teacher Education, no. 74, 215-228, DOI: 10.1016/j.tate.2018.05.011

42. Azzam Ismail, M., Keumala, N., Dabdoob, R.M. (2017). Review on integrating sustainability knowledge into architectural education: Practice in the UK and the USA. Journal of Cleaner Production, vol. 140, 1542-1552, DOI: 10.1016/j.jclepro.2016.09.219

43. Karlsson, R., Luttropp, C. (2006). EcoDesign: what's happening? An overview of the subject area of EcoDesign and of the papers in this special issue. Journal of Cleaner Production, vol. 14, no. 15-16, 1291-1298, DOI: 10.1016/j.jclepro.2005.11.010

44. Zwolinski, P., Lopez-Ontiveros, M.-A., Brissaud, D. (2006). Integrated design of remanufacturable products based on product profiles. Journal of Cleaner Production, vol. 14, no. 15, 1333-1345, DOI: 10.1016/j.jclepro.2005.11.028

45. Donnelly, K., Beckett-Furnell, Z., Traeger, S., Okrasinski, Th., Holman, S. (2006). Eco-design implemented through a product-based environmental management system. Journal of Cleaner Production, vol. 14, no. 15-16, 1357-1367, DOI: 10.1016/j. jclepro.2005.11.029

46. Boks, C. (2006). The soft side of eco-design. Journal of Cleaner Production, vol. 14, no. 15-16, 13461356, DOI: 10.1016/j.jclepro.2005.11.015

47. Johansson, G., Magnusson, Th. (2006). Organising for environmental considerations in complex product development projects: implications from introducing a "Green" sub-project. Journal of Cleaner Production, vol. 14, no. 15-16, 1368-1376, DOI: 10.1016/j. jclepro.2005.11.014

48. Karakaya, A.F., Demirkan, H. (2015). Collaborative digital environments to enhance the creativity of designers. Computers in Human Behavior, vol. 42, 176-186, DOI: 10.1016/j.chb.2014.03.029

49. Benson, E., Fine, P. (2010). Sustainable design education rethought: The case for Eco-Modernism. Design Principles and Practices, vol. 4, no. 6, 163-176.

50. Chandrasegaran, S., Badam, S.K., Kisselburgh, L., Peppler, K., Elmqvist, N., Ramani, K. (2017). VizScribe: A visual analytics approach to understand designer behavior. International Journal of Human-Computer Studies, vol. 100, 66-80, DOI: 10.1016/j.ijhcs.2016.12.007
51. Klement, M. (2017). Models of integration of virtualization in education: Virtualization technology and possibilities of its use in education. Computers \& Education, vol. 105, 31-43, DOI: 10.1016/j.compedu.2016.11.006

52. Uncles, M.D. (2018). Directions in higher education: A marketing perspective. Australasian Marketing Journal (AMJ), vol. 26, no. 2, 187-193, DOI: 10.1016/j.ausmj.2018.05.009

53. Lilley, D., Lofthouse, V. (2009). Sustainable design education - considering design for behavioural change. Engineering Education, vol. 4, no. 1, 29-41, DOI: 10.11120/ened.2009.04010029

54. Grajewski, D., Diakun, J., Wichniarek, R., Dostatni, E., Buń, P., Górski, F., Karwasz, A. (2015). Improving the skills and knowledge of future designers in the field of ecodesign using virtual reality technologies. Procedia Computer Science, vol. 75, 348-358, DOI: 10.1016/j.procs.2015.12.257

55. Tangwanichagapong, S., Nitivattananon, V., Mohanty, B., Visvanathan, Ch. (2017). Greening of a campus through waste management initiatives: Experience from a higher education institution in Thailand. International Journal of Sustainability in Higher Education, vol. 18, no. 2, 203-217, DOI: 10.1108/ IJSHE-10-2015-0175

56. Ueda, E.Sh. (2018). Student team integrating aspects of sustainability in practical design education. International Journal of Sustainability in Higher Education, DOI: 10.1108/IJSHE-08-2017-0136

57. Lofthouse, V. (2006). Ecodesign tools for designers: defining the requirements. Journal of Cleaner Production, vol. 14, no. 15-16, 1386-1395, DOI: 10.1016/j.jclepro.2005.11.013

58. Zhdanova, N.S., Zhdanov, A.A., Lymareva, J.V., Ilyasheva, E.V., Nemtseva, Yu.S., Zakharchenko, T. (2015). Design product projecting made of recycled materials. International Journal of Applied Engineering Research, vol. 10, no. 24, 45137-45141. 